\title{
Impact of Capital Account Liberalization on Economic Growth in Africa: A Case Study of South Africa
}

\author{
Khumalo S.A \\ University of Fort Hare, Department of Economics, East London Campus, South Africa; \\ alwynkhumz@gmail.com \\ Kapingura F.M \\ University of Fort Hare, Department of Economics, East London Campus, South Africa; \\ fkapingura@ufh.ac.za
}

\section{Doi:10.5901/mjss.2014.v5n20p2753}

\begin{abstract}
The increased interest in capital flows has made it imperative to understand how it impacts on economic growth. The Global drive for an interlinked world economy has increased the need for monetary authorities and Governments to able to effectively deal with any negative spins off from capital flows and also be able to take advantage of positive effects capital flows may have on an economy. The study explores the impact of the easing of restrictions on capital flows within the South African economy on Economic growth. The study analysed the relationship that exist between capital flows, measured with foreign direct investment (FDI) and portfolio investment $\left(P_{-} I\right)$ and economic growth. Empirical results revealed that there is a long-run relationship between the variables of interest. Therefore the results implies that to maximise capital account liberalization, the economy should maintain sound macroeconomic policies. This will help shield the economy from the external shocks and this maintain economic growth.
\end{abstract}

Keywords: Capital account; Capital account liberalisation; Economic growth; Foreign direct Investment, South Africa; VAR,

\section{Introduction and Background}

When the political climate in South Africa changed in the mid1990s, policies were enacted to re-integrate the country to the rest of the world. Exchange control regulations were changed and some of these changes included the relaxation of the restriction on non-resident investors, the relaxation of the rules governing corporate and institutional investors, with the aim of increasing capital flows.

The authorities opted for a gradual approach as opposed to the big bang approach, which is a form of a cold turkey policy. The gradual approach in contrast to the big bang approach allows the capital account to be liberalized over time so as to allow the economy to adjust.

Liberalizing the capital account was done with the aim of attracting international investors to come and invest in South Africa therefore increasing external savings within the South African economy. The capital inflows and the domestic savings would together stimulate economic growth as capital inflows are expected to increase productivity, leading to improved production and ultimately economic growth.

Capital account liberalisation, though still relatively young in the post-apartheid South Africa is a concept that has long intrigued economists. Over the years the focus on capital account liberalisation has begun to shift from it being a requirement for economic development and growth, to it being viewed as a potential deterrent of economic growth, in the process adding to the uncertainty already surrounding its real effect on economic growth.

Thus, the study investigates the impact capital account liberalization on economic growth in South Africa for the period 1994 to 2010. The paper is structured as follows: Following section 1 which is the introduction, section 2 looks at the overview of economic growth and capital liberalization in South Africa; Section 3 reviews relevant literature; Section 4 looks at the methodology and estimation techniques; whilst section 5 focuses on interpretation and conclusion.

\section{Overview of Capital Controls and Economic Growth in South Africa}

In the 1930s South Africa was under pervasive capital controls, which were quantitative restriction aimed at residents. 
The main idea being to encourage local savings to be channelled to domestic investment. In the 1960 s, the government then introduced dual exchange rate arrangements meant to target the non-resident investors and limit the effect of the volatile capital flows, mainly short term capital flows.

In 1961 the South African Government introduced an extra set of measures by amending the "Currency and Exchanges Act 9 of 1933". The measures implemented consisted of both targeted capital controls and pervasive capital controls. The "Currency and Exchanges Act of 1933" was the first regulation to affect South Africa though it was done under the collective name of the sterling area. The sterling area comprised of countries which adopted the British sterling or had their currencies pegged against British Sterling. South Africa was under the sterling Area from 1933 till its demise in the mid-1970s. This was so even after the $14^{\text {th }}$ of February 1961 when the South Africa economy changed from using the South African pound to the South African Rand.

In his article Henshaw, (1996) highlights that South Africa benefitted from the sterling area because it was Britain's biggest source of agricultural produce at that time, and was able to export to Britain at constant rates, was able to sell its gold produce through London which was a cheaper and more efficient system and Britain was a source of capital that was a vital to the development of the mining industry.

According to Schulze (n.d: 01) the "Currency and Exchanges Act 9 of 1933" was introduced to curb the outflows of capital to countries that were not in the sterling area. This means that at the time the countries within the sterling area could experience capital flows amongst themselves but not with a non-member country. This maintained the amount of reserves held in the sterling area.

In 1960 the Sharpeville massacre, which was the climax of the build-up of political tensions and instability in the early 1960's was a trigger for the amendment of the "Currency and Exchanges Act 9 of 1933." The political instability negatively affected the credibility and ultimately the image of South Africa in relation to foreign countries. The Government had to make the amendment to try and limit the impact of a pending crisis which was brought about by capital flight.

Having built up its gold and currency reserves by participating in the sterling area, South African monetary authorities were faced with serious crisis whereby its foreign and gold reserves were falling. Reserves were falling as a result of the political instability. The unrestrained capital outflows were putting pressure on the capital account and ultimately the balance of payments, which forced the monetary authorities to use the reserves they had to finance transactions. The result was that the foreign currency reserves and the gold reserves dropped significantly.

Although foreign reserves in 1960 were already declining, the drop in reserves during April was more pronounced. There was $29 \%$ drop in the month of April, immediately after the massacres. The $29 \%$ drop was a significant in relation to the drops in February and March which were at $9 \%$ and $14 \%$ respectively. The drop in foreign currency reserves is attributed to the negative effect of a drop in capital inflows, which meant reserves, had to be used to finance the current account balance.

\subsection{Capital account liberalisation (1995- 2009)}

The post-apartheid era was ushered in by a Government of national unity. The Government sought to normalize the country and rebuild it. Under the reconstruction and development policy, the Government saw the need to restructure the economy. The debt crisis, high unemployment levels and falling GDP per capita

The Government chose to take a less radical approach to removing the controls that were present in the economy. The controls were affecting both the current account and the capital account. The authorities adopted the gradually approach to relaxing capital account controls. The gradual approach allowed for the sequential removal of controls on the capital account that existed in the economy based on the strength of structural economic reform. The monetary authorities based their choice on the recommendations made by studies such (McKinnon, 1993) and (Edwards, 1984).

Grové(n.d) highlights the general sequence that was followed focused on the non-residents, then the current account, then resident institutions and the residents. To kick start the process, the financial rand was replaced by a unified currency. Just as in 1983, the dual exchange rate system was scrapped. The difference this time was that the political climate was in a better state and the financial discount was around ten percent. The timing of the liberalisation of the capital account in 1995 was better than in 1983. The timing of capital account liberalisation is an aspect that is vital to the success of the policy. The table below highlights some of the relaxations that have been carried under the gradual opening up of the capital account 
Table 2.1: A summary of relaxations on controls

\begin{tabular}{|c|c|}
\hline 1/04/1995 & - Resident companies could invest abroad and raise foreign funds against their balance sheets \\
\hline $14 / 07 / 1995$ & $\begin{array}{l}\text { - The use of asset swaps was by institutional investors was allowed. The institutional investors still had to get } \\
\text { approval to be able to invest in foreign assets using the swaps. }\end{array}$ \\
\hline 21/06/1996 & $\begin{array}{l}\text { - The amount of foreign assets an institutional investor could acquire via swaps was increased to } 10 \% \text { from } 5 \% \text {. } \\
\text { - The purchase of outright foreign investments was legalized and limited to } 10 \% \text { of an institutions total asset value. }\end{array}$ \\
\hline $01 / 07 / 1997$ & $\begin{array}{l}\text { - Registered fund managers offering private client asset management were included into the list of institutional } \\
\text { investors. }\end{array}$ \\
\hline 22/07/1997 & - Only asset swaps transactions that involved an exchange in cash or portfolio assets were allowed. \\
\hline $21 / 02 / 2001$ & $\begin{array}{l}\text { - The asset swap mechanism for new transactions was terminated. } \\
\text { - New foreign investments by log-term insurers, pension funds and unit trust management companies were, } \\
\text { however, limited to } 10 \text { per cent of the net calendar } 2000 \text { inflow, subject to the overall asset limits. }\end{array}$ \\
\hline $23 / 02 / 2001$ & - Individual residents above 18 years could invest up to R750 000 abroad. \\
\hline 2003 & $\begin{array}{l}\text { - Dividends from foreign arms of resident companies could be used to invest in foreign direct investments after } \\
\text { approval by authorities. } \\
\text { - Allow resident companies to open foreign currency accounts. }\end{array}$ \\
\hline $07 / 10 / 2009$ & $\begin{array}{l}\text { - Foreign Capital for residents increased to R4 million from R2 million } \\
\text { - Increase company limit to invest abroad from R50 million to R500 million } \\
\text { - Scrapping of the 3:1 ratio for local borrowing on non-residents who own 75\% stake and over in companies. }\end{array}$ \\
\hline
\end{tabular}

Source: Author's compilation

\subsection{Economic growth under capital controls}

Figure 2.1 GDP at constant prices (2005) R Million

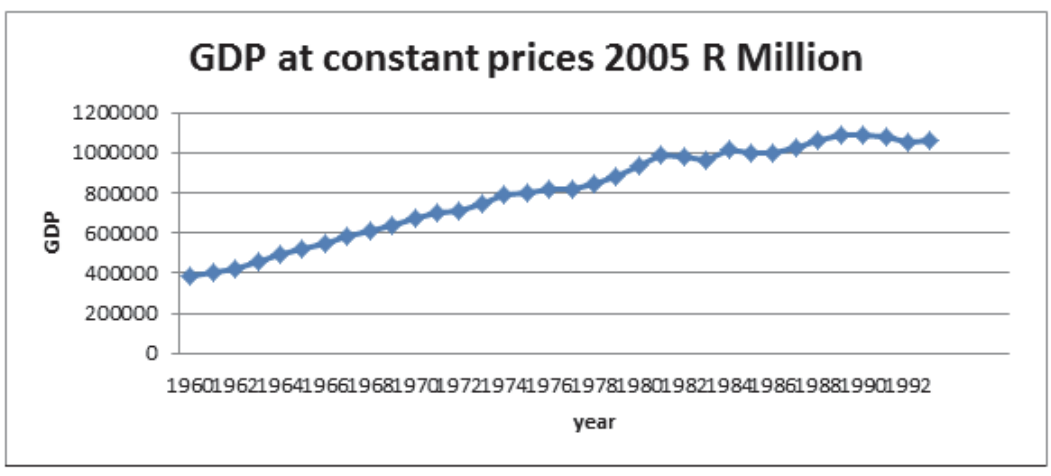

Source: adapted from SARB

Under capital controls the economic output increased in a linear form. Looking at the graph above output attained in 1960 was within doubled in 14 years. Fedderke \& Simkins, (2009:26) Note that using growth accounting the main driver of economic output growth was capital accumulation. The increase in output is attributed to the increased use of physical factors of production. This is in line with the growth theory that was put forward by economists such as Harod and Domar who are credited with the Harod-Domar framework, which basically was of the view that to increase output the factors of production and to also be increased in the same proportions as substitution between factors of production was not possible.

The economy experienced an improvement towards infrastructure in the mining sector which led to increased output in mining, and the discovery of more mineral deposits helped increase the output in mining. The increased capital realized from mining was then used to for diversification by the venturing into agriculture and manufacturing, as was noted by Hackland, (1980:03).

Manufacturing grew at its fastest during the 1950s. The development of new industries within manufacturing was 
the main reason for the increase in manufacturing within South Africa. The development of the motor industry, the diamond, the steel industry and even the textile industry all contributed to the growth. The increased investment in factories and in the use of factors of production including labour meant capital accumulation was vital under capital controls. The supply of labour was readily available therefore the cost of production was cheap with regards to labour input. The focus on the factors of production is what drove the growth of output prior to capital account liberalisation.

For the period from 1960 - 1980 the amount of investment the government and public corporations spent on capital accumulation was almost always equal to what the private sector was spending. This highlights that the focus of the government and its policies was towards capital accumulation and it helped encourage the private sector do the same.

The period under 1980 - 1994 saw the economy experienced a slowdown in terms of economic growth. The increase in gold price which helped the economy in the early 1980s boosted the growth of the economy but with its subsequent drop, the performance of the economy began to decline. The uncertainty that existed at the time was a catalyst for drop in economic growth. According to Fedderke \& Simkins, (2009) the 14 years prior to independence in 1994 saw the economic growth slow to an extent that GDP per capita fell by approximately eighteen percent. This can be seen from the diagram below.

The rate of increase as can be seen from the graph above shows that after a period of fourteen years from 1960, the output doubled but from 1980 to 1994, the rate of growth was significantly slower relative to the 14 year period from 1960. One reason for this drop in economic output could because of the drop in investment per capita.

Capital stock which has a medium to long term lifespan began to decline in the mid-1980s. This meant the based for economic growth from the investment point of view was shrinking, and thus did not predict a good future trend for economic growth. The graph of economic output shows that it has been on a decreasing trend, although that trend has been reversed after the turn of the century.

Figure 2.2 infrastructural Investment in South Africa

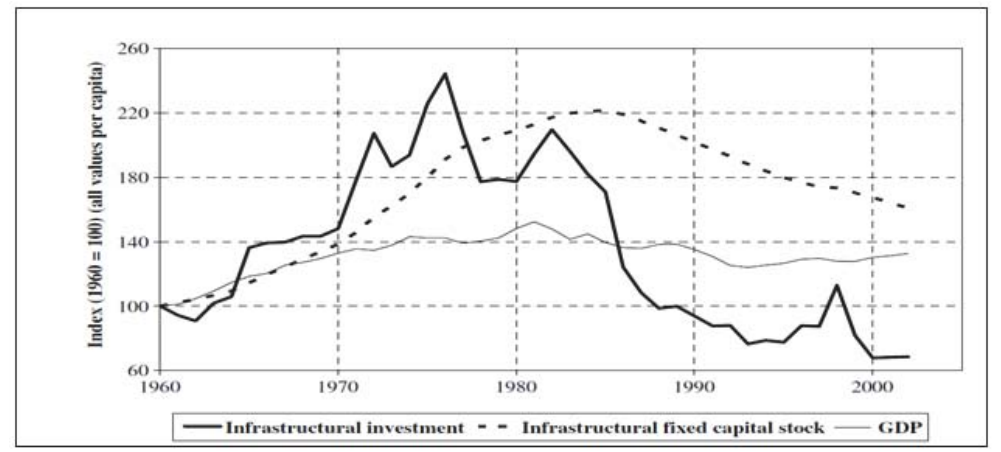

Source: (Perkins, Fedderke, \& Luiz, 2005)

Infrastructural investment was peaking, foreign investment was the highest contribute among three sources of capital, namely household saving, corporate savings and foreign investment. Household savings and corporate saving can be combined to be known as domestic savings. With foreign investment towards capital formation after capital account liberalisation, the reversal of the effect of a drop in infrastructural investment has begun. The expectation is that in the period under 2005-2009 infrastructural investment will increase as will economic output.

Table 2.2 Financing of gross capital formation (\% of GDP) (R million)

\begin{tabular}{|l|c|c|c|c|c|c|}
\hline Period & $1960-1969$ & $1970-1979$ & $1980-1989$ & $1990-1994$ & $1995-2004$ & $2005-2009$ \\
\hline Household saving & 0.10266 & 0.1793 & 0.38335 & 0.81358 & 0.45523 & $(0.19449)$ \\
\hline Corporate saving & 0.03945 & 0.16203 & 0.7939 & 2.076776 & 3.21219 & 2.60875 \\
\hline Foreign investment & 0.0055 & 0.7132 & $(.219684)$ & $(0.4239)$ & 0.65854 & 6.34206 \\
\hline
\end{tabular}

Source: adapted from SARB (2010) 


\subsection{Economic growth under Capital Account Liberalisation}

The start of the process of capital account liberalisation witnessed an increase in the rate of GDP growth. Within ten years the economic output had increased by approximately fifty percent. This is in contrast to the fourteen year period prior to capital account liberalisation.

This increase in economic output occurred when investment on infrastructure was declining just as was the case fourteen years before capital account liberalisation. This means the effect of investing in factors of production can be said to have been reduced. Therefore the probable effect that was now dominating can be said to be productivity of the available factors of production. Du Plessis \& Smit, (2007:07) list total factor productivity (TFP) as the main driver of growth in economic output.

Figure 2.3 GDP constant prices $20051994-2009$

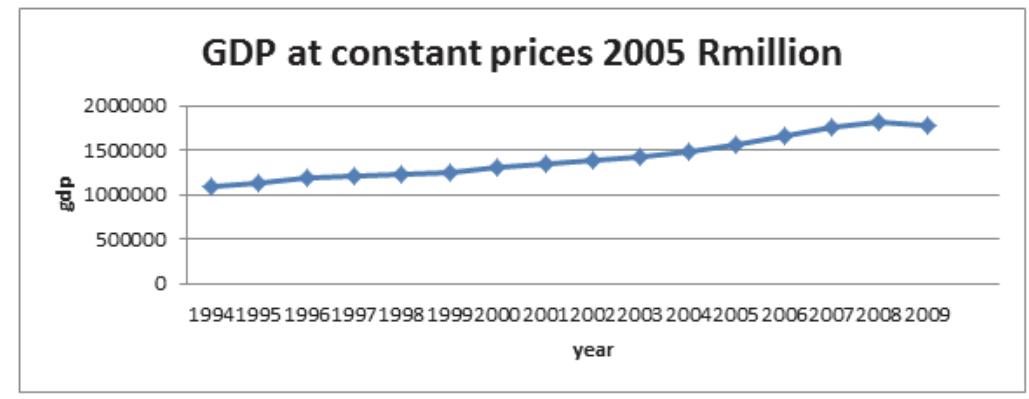

Source: adapted from SARB (2010)

TFP is driven by efficiency and improvements in technological processes rather an increase in factors of production. This means for a given level of factors of production, the output can be increased if changes are made to processes and attention is given to efficiency.

One aspect of productivity that has come to the fore in South Africa is labour productivity. The graph below shows that towards independence in 1994, the productivity levels within the labour force were beginning to pick up. After capital account liberalisation productivity in non-agriculture sectors began to increase significantly, while the productivity levels of manufacturing which had dropped after the debt crisis had begun also improved to previous levels. At the beginning of the $21^{\text {st }}$ century manufacturing labour productivity continued to increase to new highs but then dropped in 2009 while the non-agriculture sectors experienced a dip in labour productivity at the turn of the century which stabilized at were maintained at the approximate level of 80 in the index.

The combined improvement in labour productivity was part of the driving factor behind the increase in economic output. This trend is in line with the increase in foreign investment coming into the economy. Although some of the foreign investment was used for infrastructural development the main benefactor of this investment looks to have been the TFP side. The existing infrastructure was used to increase economic output while in previous years the output had stagnated or even declined. This is attributed to TFP.

Looking at the average annual GDP rate, the trend line shows that prior to 1994, GDP was on a general decline but post 1994 the trend has been one of an increase. This can be attributed to the number of factors which include the political environment and macroeconomic policies. Before 1994 the variation of the levels of the GDP rate was wide. The standard deviation is higher than that of post 1994. Post 1994 shows stability within the levels of GDP growth rates.

\section{Review of Relevant Literature and Theoretical Framework}

When defining capital account liberalisation Henry (2007:1) highlighted that it is a shift in Government policy from a system that limited capital flows to and from foreign economies to a system that encourages capital flows to and from foreign economies. This means there should be a well pronounce and clear move from any previous policy that encouraged controls.

Economic theory says that capital account liberalisation is expected to result in a situation whereby capital from 
capital rich countries will flow to capital poor countries based on the view that capital account liberalisation leads to the efficient allocation of resources. Economic theory also highlights that there is an expectation that capital will flow from economies with low rate of return which are usually the developed countries to the developing which have significantly higher levels of return.

Fischer (1997:4) highlights how the possibility of capital account liberalisation influences the policies within the local economy. Capital account flows are believed to be sensitive to macroeconomic policies, therefore the policies set out by authorities within the economy will have a huge influence on capital flows. In order for the capital flows within the economy not be negatively affected by market forces the policies implemented should be good policies as inappropriate policies will have a disastrous effect on the economy.

It has to be acknowledged that for the liberalisation to be effective there is the need for sound macroeconomic policies as highlighted by (Fischer, 1997). There is a need to properly manage the interest rate, the exchange rate and the performance of the economy as a whole so as to aid in the growth of the economy. This means that the performance of the financial system is of the utmost importance. The stability of the financial system will be a priority, highlighting the importance of regulation and monitoring of the financial sector by the authorities. Free capital accounts rely less on bureaucrats and empower the monetary policy authorities, thus avoiding the problem that arises out of poor resource allocation by bureaucrats.

There are a number of benefits which accrue from capital account liberalisation. When capital controls are removed, the result is there will be an inflows and outflow of capital. The capital flows will be either short term capital or long term capital, popularly referred to as foreign direct investment. Economic theory is divided on the effects of short term capital. The neo-classical theorists are of the view short term capital will improve the balance of payments. They say that short term capital has similar effects as trade liberalisation. In reference to opening up the capital account the neoclassical economist are of the view that short term free capital inflows have a similar effect as trade liberalisation, that is are beneficial to an economy. (Gray \& Dilyard, 2005) in their book highlight that, neo classical economists are of the view that external free short term capital flows will result in a general improvement in aggregate consumption pushing the demand for goods and services up, which will translate to an improvement in production. Based on the effect of trade in the Hecksher -Ohlin framework, (Epstein, 2005) notes that economic theory expects that capital account liberalisation will result in an increase in productivity via the factor of production which is abundant.

(Eichengreen, 2004) notes that economic theory is of the view that capital flows will bring into an economy resources, technological knowhow and also mould the local institutions into better models that will improve economic performance and economic output.

Capital account liberalisation is anticipated to aid the development of financial markets because of its positive effect on the liquidity levels of the different asset in the financial markets. (Shirakawa,2009:1) notes that the liquidity of the financial markets has become a concept, which cannot be side-lined when creating policies for the economy and points out that the bank of Japan in its capacity as the lender of last resort has the role of being the caretaker of liquidity within the Japanese economy. Capital account liberalisation will affect the financial markets, influencing the liquidity levels of the different asset classes in the financial markets. The main asset classes are grouped as capital, equity and money.

Another way Capital account liberalisation aids the development of financial markets is through the technological transfers, as it gives foreign investors the right to purchase shares and bonds in the country's markets, while simultaneously allowing domestic investors the right to invest abroad. The ability to trade in foreign securities is a process economists has termed migration of securities activities, will require that financial markets be more interlinked. The integration of the domestic financial markets and the foreign financial markets means gives rise to competition and improved efficiency, which is achieved through the improvement of technology which the domestic financial markets import from the foreign financial markets and thus improve on their intermediation.

(Gruben and McLeod, 2001), Notes that capital account liberalisation in itself will help regulate the monetary policy as it will lead to a situation whereby if there is a loose monetary policy then, capital account liberalisation will discipline the authorities. Since capital account liberalisation will result in the local market accessing external markets with the ability to invest and thus diversify portfolios a loose monetary policy will mean it is possible for the local currency to depreciate as local demand for foreign currency increases and the reserves drop within the economy. An out of control depreciation of the local currency can result in inflation.

Economists have tied capital account liberalisation with the development of financial markets. (Bacchetta,1992: 466), in an article pointed out that it is possible to have the liberalisation of the financial markets and the capital account occur at the same time. The article further states that the liberalisation can be in two ways, either as a policy decision whereby the authorities voluntarily remove restriction in the financial sector that are coupled with the capital account restrictions. Also the liberalisation of the financial markets can be a result of market forces that arise because of the 
liberalisation of the capital account as the local market becomes in direct competition with the external markets. The liberalisation of the financial markets can be in a number of forms, but (Dulbecco et al,2003: 74) note the following as the main forms (i) the deregulation of interest rates (ii) the introduction of competition between the different channels of financing and (iii) the external opening of the financial system.

According to (Fischer, 1997: 3) capital account liberalisation is the trigger for the development of an economy that is why all developed economies have open capital accounts. In other words in order for an economy to develop it will need to have an open capital account. (Fischer, 1997) was of the view that for an economy to develop, it has to be integrated with other economies. This would enable it to benefit from the transfers made by the other economies. His view was in line with the observation that all developed countries had open capital accounts.

(Henry, 2003) notes that the cost of capital is composed of two variables, the risk free rate and the risk premium. Both these variables are expected to fall as a result of capital account liberalisation. (Epstein, 2005: 17) notes that opening capital accounts should increase growth by enhancing the potential for risk diversification. The fall in the risk free rate is attributed to the increased potential for risk diversification. The drop in the risk premium is attached to the domestic market and Economic theory highlights that financial liberalisation which improves financial depth and development of the domestic market can arises through indirect channels as a result of capital account liberalisation. Therefore capital account liberalisation is expected to reduce the cost of capital.

However, there are dangers associated with capital account liberalization. (Singh, 2003: 4) highlights that the theory on free trade which is advocate for by the neo classical economists has its shortcomings. The shortcomings are viewed from the point of view of being operational as the article highlights that there is need for stringent policies which are not traditionally adopted.

Other economists argue and say short term capital is extremely volatile and thus if an economy relies on short term capital inflows, it is likely to experience a financial crisis especially with developing economies, which are still, likely to be still developing their financial systems. This is a view supported by (Rajan \& Prasad, 2005), who highlight the possibility of the domestic currency appreciating to unanticipated levels when a situation arises whereby there are sudden inflows of short term capital, the effect is that the economy cannot adjust fast enough and thus leading to a pressure situation. This is one example of an external shock that is not well dealt with by the financial sector, and the result will be the unanticipated appreciation of the domestic currency.

(Yew, 2008) in a book highlights how the new Keynesian theory postulates that in general the information available to borrowers is not the same as that available to lenders. With capital account liberalisation this scenario becomes more pronounced as the borrowers the domestic economic agents will have more knowledge as compared to the lenders who are foreign economic agents in relation to the domestic market. This will raise the problem of adverse selection. In order to protect themselves lenders will then only invest in projects that they deem will give them a predetermined rate of return, which in most cases tends to be very high and excludes a significant investments projects. This will result in the economy failing to attain the optimal level of economic welfare.

Overall, a number of studies have been carried out to establish the relationship between capital account liberalization and economic growth; however, conclusions have been varied. There are studies which have found a positive relationship between economic growth and capital account liberalization (Arteta et al 2001); (Bekaert et al 2001); (Glick et al 2004); (Edwards 2001). There are also studies which have found a negative relationship between capital account liberalization and growth (Ferreiro et al 2008; (Aker and Aker 2009); (Licchetta 2006); (Milesi-Ferretti and Grilli 1995); (Kaminsky and Reinhart's 1999). On the other hand there are studies which have concluded that there is no relation between the two variables (Alfaro, Chanda, kalemali-Ozcan, \& Sayek 2004; Tang 2006; Rodrik 1998). The relationship between the two is inconclusive therefore.

\section{Methodolody and Estimation}

The study will rely on the endogenous growth model. With the endogenous model, the long run growth rate is not determined separately from the model but is determined by the model itself. The advantage of the endogenous model is that it has the underlying assumption that there are non-decreasing returns based on the selected factor of production as highlighted by (Seth \& Varma,2009). This allows the study to predict that any long run growth changes in South Africa under the period under review will be as a result of changes in capital flows. The model is a linear relationship between growth rate and the independent variables in the form:

$Y=f(K, L)$. 4.1

Adapting the linear growth model to the study it will follow the set up for the basic benchmark growth regression, which was used by Epstein, (2005), whereby the study seeks to regress economic growth against capital flows and the 
country specific conditions, which will also include the financial sector development variables. The basic set up for the benchmark growth regression is in the form:

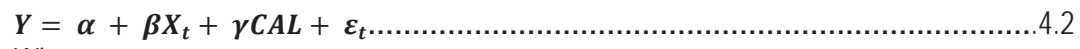

Where

$Y$ represents GDP growth

CAL refers to the variable for capital flows

$\mathrm{X}$ represents a vector of control variables

The "two gap" theory explains the importance of the savings gap and the import gap in relation to economic growth. The vector of control variables will have to represent channels within the economy that will facilitate the effect of savings, and the effect of imports in influencing economic performance.

The empirical model is as follows:

$Y=\alpha_{0}+\alpha_{1}$ FDI $_{T}+\alpha_{2} P_{.} I_{T}+\alpha_{3}$ CLAIMS $_{T}+\alpha_{4}$ PRODUCTIVITY $_{T}+\alpha_{5}$ TRADE $_{T}+\mu_{T} \ldots \ldots . .3$

\subsection{Estimation Techniques}

The first step in our analysis is to test for stationarity of our variables. (Gujarati, 2003) suggest that a stationary stochastic process implies that the mean and variance are constant overtime, and the covariance between two periods depends only on the lag between the two time periods and not the actual time at which the covariance is computed. This implies therefore that a non-stationary time series will have a varying mean or varying variance or both. Using non stationary data may therefore result in spurious regressions. It is imperative therefore to analyse the time series properties of the data.

The statistical and time series properties of the data set were first carried out using the Augmented Dickey-Fuller (ADF) and Phillips-Perron (PP) to test for unit root. (Mallik and Choudhry 2001) and (Ahmed and Mortaza, 2005) point out that the PP test can properly distinguish between stationary and non-stationary time series with a high degree of autocorrelation and presence of structural break.

The study will employ the Johansen cointegration approach to establish if there is a long-term relationship between the variables of interest. The Johansen approach is based on the vector autoregressive model and assumes all the variables are endogenous. The variance decomposition and impulse response will be constructed.

Data from 1994 to 2010 for the study was sourced from the South African Reserve Bank (SARB). The data for all variables (capital flows, private sector claims, human productivity, and trade balance) were all obtained from the online statistical query under the SARB website.

\section{Econometric Procedure, Results and Conclusion}

Time series properties of the data were carefully evaluated through the Augmented Dickey Fuller (ADF) and Phillip-Peron (PP) tests. All variables were regarded as non-stationary at their levels. The variables were tested for stationarity at first differences. The results indicated that all variables are stationary. The results confirmed therefore that differencing once was all that was required to bring these variables to stationarity at all levels of significance. This suggests that our variables are integrated of order one I(1). Having established the existence of unit roots, cointegration tests were conducted.

The optimal lag order was determined empirically. Based on several criteria (AIC, SIC, FPE, LR and HQ), a lag order of 1 , which produced a stable VECM, was selected.

The Johansen Cointegration test was conducted and the results are shown in table 5.1: 
Date: 06/16/11 Time: 16:07

Sample (adjusted): 1975Q3 1994Q1

Included observations: 75 after adjustments

Trend assumption: Linear deterministic trend

Series: GDP FDI P_ I CLA PRO TRA

Lags interval (in first differences): 1 to 1

Unrestricted Cointegration Rank Test (Trace)

\begin{tabular}{ccccc}
\hline \hline $\begin{array}{c}\text { Hypothesized } \\
\text { No. of CE(s) }\end{array}$ & Eigenvalue & $\begin{array}{c}\text { Trace } \\
\text { Statistic }\end{array}$ & $\begin{array}{c}0.05 \\
\text { Critical Value }\end{array}$ & Prob. $^{* *}$ \\
\hline \hline None * & 0.525797 & 159.1466 & 95.75366 & 0.0000 \\
At most 1 * & 0.470258 & 103.1875 & 69.81889 & 0.0000 \\
At most 2 & 0.339355 & 55.53507 & 47.85613 & 0.0081 \\
At most 3 & 0.194576 & 24.44469 & 29.79707 & 0.1823 \\
At most 4 & 0.084461 & 8.215740 & 15.49471 & 0.4426 \\
At most 5 & 0.021076 & 1.597580 & 3.841466 & 0.2062 \\
\hline \hline
\end{tabular}

Trace test indicates 3 cointegrating eqn(s) at the 0.05 level

* denotes rejection of the hypothesis at the 0.05 level

**MacKinnon-Haug-Michelis (1999) p-values

Unrestricted Cointegration Rank Test (Maximum Eigenvalue)

\begin{tabular}{ccccc}
\hline \hline $\begin{array}{c}\text { Hypothesized } \\
\text { No. of CE(s) }\end{array}$ & Eigenvalue & $\begin{array}{c}\text { Max-Eigen } \\
\text { Statistic }\end{array}$ & $\begin{array}{c}0.05 \\
\text { Critical Value }\end{array}$ & Prob. $^{* *}$ \\
\hline \hline None * & 0.525797 & 55.95904 & 40.07757 & 0.0004 \\
At most 1 * $_{\text {At most 2 }}^{*}$ & 0.470258 & 47.65245 & 33.87687 & 0.0006 \\
At most 3 & 0.339355 & 31.09038 & 27.58434 & 0.0170 \\
At most 4 & 0.194576 & 16.22895 & 21.13162 & 0.2118 \\
At most 5 & 0.084461 & 6.618160 & 14.26460 & 0.5352 \\
& 0.021076 & 1.597580 & 3.841466 & 0.2062 \\
\hline \hline
\end{tabular}

Max-eigenvalue test indicates 3 cointegrating eqn(s) at the 0.05 level

* denotes rejection of the hypothesis at the 0.05 level

**MacKinnon-Haug-Michelis (1999) p-values

Source: Author's Computation using Eviews 7

As indicated in table 5.1, the Johansen cointegration test proved evidence of three cointegrating vectors. Based on the results of cointegration, the VECM was specified which provided the parameter estimates for the long-run relationship.

Normalized cointegrating coefficients (standard error in parentheses)
GDP
FD
P_I
CLA
PRO
TRA

$1.000000 \quad 25.15116 \quad 17.57894 \quad 0.087982-19234.803 .154974$

(3.29059) (2.44730) (0.22508) (5508.63) (1.53169)

The normalised equation indicates that FDI, P_I, PRO and TRA are significant in the model. To get the t-statistic the coefficients are divided by the standard error term for each. FDI, P I and TRA are expected to have a positive relationship with GDP.

The empirical results indicates that an increase in FDI, P_I AND TRA result in an increase in GDP. This is in line with economic expectations. PRO has a negative coefficient which indicate that there is a negative relationship between PRO and GDP. A drop in PRO will have a positive impact on GDP growth. This relationship does not have an economic backing. The general view is that the relationship is positively correlated.

CLA which represent the financial sector development is insignificant even though it has a positive coefficient. CLA is considered insignificant in the model as shown by the results. This result is consistent with (Arteta, et al, 2001). The authors made an interesting observation stating that financial depth does not play a role in aiding the economy to benefit 
from capital account liberalisation. However, the authors also note that capital account liberalisation will aid economic growth provided the macroeconomic imbalances are removed and is the sequencing of trade and financial liberalisation are done in the right order. This is in consonance with (Bekaert, et al 2001) who noted that most countries had higher economic growth rates five years after liberalisation than the five years prior to liberalisation. The authors concluded that approximately $40 \%$ of the increase in economic growth is attributed to liberalisation.

\section{Conclusion}

The study set out to analyse the impact of capital account liberalization on economic growth in South Africa. After an analysis of literature an endogenous model was adopted to analyse the relationship between the variables of interest. Empirical results indicated that all measures of capital account liberalization are significant and carries the correct sign. In conclusion, the study does find that opening the capital account in the case of South Africa did increase capital flows and also increase the grow rate of economic production. The effect of intermediation was minimal as it became less pronounced after liberalisation.

Coupled with the increase in the economic growth rate the economy also became more susceptible to an economic crisis. This means that the benefit of opening the capital account can easily be nullified by a financial crisis. This is in line with the view taken by economist against the neo classical view. Economists against the neo classical view put forward the view that the short term capital flows are volatile and subject to abrupt changes and thus have negative effects on the economy. Therefore as in Gray and Dilyard (2005) capital account liberalisation dependent on short term inflows will result in the possibility of a financial crisis particularly in developing countries.

\section{References}

Ahmed S. and Mortaza G., Inflation and Economic Growth in Bangladesh, 1981- 2005, Policy Analysis Unit (PAU) Working Paper 0604 (2005)

Aker, S. and Aker, A. H., Capital Account Liberalization and the Exchange Rate Regimes in Developing Countries, Banking and finance letters : International economic Society, vol 1 (5-9) (2009)

Alfaro, I., Chanda, A., kalemali-Ozcan, s., \& Sayek, S., FDI spillovers, Financial markets and economic growth. Retrieved 07 29, 2010 , from IMF: http://www.imf.org/external/pubs/ft/wp/2003/wp03186.pdf

Arteta, C., Eichengreen, B., \& Wyplosz, C., When Does Capital Account Liberalization Help More than It Hurts? : NBER working paper 8414, (2001)

Bacchetta, P., Liberalization of Capital Movements and of the Domestic Financial System. Economica, New Series, Vol. 59, ( 236) , 465474. (1994)

Bekaert, G., C.Harvey, \& Lundblad, C., Does financial liberalization spur growth? NBER working paper 8245, (2001)

Du Plessis, S. and Smit, B., South Africa's growth revival after 1994:Stellenbosch Economic Working Papers: 01/061. (2007)

Dulbecco, P. H., Courbis, B., \& Allegret, J. P., Financial Liberalization and Stability of the Financial System in Emerging Markets: The Review of International Political Economy, Vol. 10, (1) , 73-92 (2003)

Edwards, S., The order of liberalization of the balance of payments: World Bank working paper number 710, (1984)

Edwards, S., Capital mobility and economic performance, Are emerging economies different?:NBER working paper 8076. (2001)

Eichengreen, J. B., Capital flows and crises. MIT press paperback. (2004)

Epstein, G. A., Capital flight and capital controls in developing countries. Massachusetts: Edward Elgar publishing Itd. (2005)

Fedderke, J., \& Simkins, C., Economic Growth in South Africa since the late nineteenth century: ECONRSA working paper number 138. (2009)

Ferreiro, J., Correa, E., \& Gomez, C., Has Capital Account Liberalization in Latin American Countries Led to Higher and More Stable Capital Inflows?: International Journal of Political Economy, vol. 37, ( 4) , 31-63. (2008)

Fischer, S., Capital Account Liberalization and the Role of the IMF. Retrieved April 20, 2010, from http://www.piie.com/fischer/ pdf/Fischer141.pdf. (1997)

Glick, R., Guo, X., \& Hutchison, M., Currency Crises, Capital Account Liberalization, and Selection Bias. Retrieved 11 19, 2010 , from http://www.ny.frb.org/research/conference/2004/fin_global/hutchison.pdf. (2004)

Gray, P., \& Dilyard, J. R., Globalization and financial instability. Cheltenham: Edward Elgar publishing limited. (2005)

Grové, C. (n.d.). Retrieved 10 16, 2010, from http://www.anwaltamkap.com

Gruben, W. C., \& McLeod, D.,Capital Account Liberalization and Disinflation in the 1990s. Retrieved 01 07, 2011, from NBER: http://ideas.repec.org/ p/fip/feddcl/0101.html. (2001)

Hackland, B., The Economic and Political Context of the Growth of the Progressive Federal Party in South Africa, 1959-1978: Journal of African studies, 7(1) 1980

Henry, P., Capital Account Liberalization: Theory, Evidence, and Speculation :.Journal of economic Literature, vol XLV, (2007)

Henshaw, P. J., Britian,South Africa and the Sterling Area: Gold Production, Capital Investment and Agricultural Markets: The Historical Journal, 39 (1), (1996) 
Kaminsky, G. L., \& Reinhart, C. M., AssociationThe Twin Crises: The Causes of Banking and Balance-Of-Payments Problems :The American Economic Review, 89, (3 )(Jun., 1999), pp. 473-500. (1999)

Licchetta, M., Macroeconomic effects of capital account liberalization in emergiing countries. University of Roma working paper 1 (2006)

Mallik G., Chowdhury A., Inflation and Economic Growth: Evidence from Four South Asian Countries, Asia-Pacific Development Journal, 8, (1), 2001.

McKinnon, R., The order of economic liberalization. Baltimore maryland: John Hopkins university press. (1993)

Milesi-Ferretti, G. M., \& Grilli, V., Economic Effects and Structural Determinants of Capital Controls: International Monetary Fund, Vol. 42, No. 3 pp. 517-551. (1995)

Rajan, R. G., \& Prasad, E. S., Controlled Capital Account Liberalization: A Proposal. IMF Policy Discussion Paper PDP/05/xx .

Rodrik, D., Who needs capital-account convertibility? : Prinston international Finance (1998)

Schulze ,H. (n.d.). EXCHANGE CONTROL: South Africa further relaxes exchange controls. Retrieved 08 30, 2010, from off shore investments: http://www.offshoreinvestment.com/residency/pdfs/sa4.pdf

Seth, A., \& Varma, S., Capital Account Convertibility and Growth: A Developing Country Perspective: Decision 36 (1) (20009)

Shirakawa, M., Financial System and Monetary Policy Implementation. Tokyo.(2009)

Singh, A., Capital Account Liberalisation, free long term capital flows, financial crisis and economic development. Eastern economic journal 29 (2) pp191-216 (2003)

Tang, D. (2006). The effect of financial development on economic growth: evidence from the APEC countries1981-2000: Applied Economics 38 (16), (2006)

Yew, c., Capital account liberalization. Norderstedt.Books on demand Gmbh. (2008) 